\title{
Pengaruh Konseling Kesehatan Terhadap Penurunan Tingkat Kecemasan Pasien TBC Paru Di Puskesmas Campurejo Kota Kediri
}

\author{
Hengky Irawan \\ Dosen Akper Dharma Husada Kediri
}

The Influence of Health Counseling towards to reduce Anxiety Level

of Lung Tuberculosis patient's in Puskesmas Campurejo of Kediri City

\begin{abstract}
Lung Tuberculosis (TBC) is contagious disease caused by Mycobacterium Tuberculosis germ. The treatment and supporting facilities have been available. The Government effort to overcome this disease by Directly Observed Treatment Shortcourse (DOTS). The old treatment and expensive cost caused the patient feels anxiety. The Nurse's role is to overcome the anxiety through health counseling. It is a kind of method used to solve the patient's problem. The research aims to know the influence of health counseling toward the reduction of anxiety level in lung TBC of the patient in Puskesmas Campurejo Kediri city. This research is called Pre-Experimental with One Group PretestPosttest design. The samples consists of 25 respondents, taken with Non Probability Sampling by type Pusposive Sampling Method, which new lung TBC patient's. Variable measured in this research are patient's anxiety level before and after given the health counseling. The result shows that before given the health counseling, 32\% patient experience in low, middle, and high anxiety level, while $4 \%$ patient experience in panic. After given health counseling, the result shows that $44 \%$ patients experience in middle anxiety level, $36 \%$ patients experience in low anxiety level, $28 \%$ patients experience in high anxiety level. These data indicate that $28 \%$ respondents show the alteration in reduction of anxiety level, $72 \%$ do not show the alteration in reduction of anxiety level. The result shows that $80 \%$ respondents experience the alteration in reduction of anxiety level while $20 \%$ respondents do not experience this. Based on the results of Wilcoxon $(\alpha=5 \%)$, the level anxiety in health counseling of towards the reduction of anxiety level in Lung TBC of the patients. For the next research hope to make a contact and therapeuticall communication with patients.
\end{abstract}

Key words: Lung TBC, anxiety level, health counseling

\section{Pendahuluan}

Penyakit Tuberkulosis (TBC) Paru merupakan penyakit menular yang disebabkan kuman Mycrobacterium Tuberculosis. Menurut Survey Kesehatan Rumah Tangga ( SKRT ) tahun 1996 menyebutkan TBC penyebab Kematian ke 2 setelah penyakit kardiovaskuler. Menurut laporan WHO (1999), Indonesia merupakan penyumbang penyakit TB terbesar nomor tiga setelah india dan cina.(Dep. Kes RI tahun 2003:2). Cara penularan TBC melalui droplet (percikan dahak) pada waktu penderita TBC batuk, bersin atau berbicara. Infeksi paru-paru (tuberkulosis paru) menimbulkan gejala batuk-batuk kronis yang berdahak kadang batuk berdarah (hemoptisis) dan secara umum pasien mengalami anoreksia dan penurunan berat badan,tubuh terasa lelah dan lesu,demam dan sering kedinginan (Soedarto, 2009:171).

Berbagai upaya telah dilakukan oleh pemerintah dalam penanggulangan TBC Paru salah satunya adalah kegiatan pelaksanaan Strategi DOTS (Directly Observed Treatmant Shortcourse). Pemberantasan TBC di Indonesia dengan strategi DOTS bertujuan mencegah/menghindari resistensi, 
ketaatan dan keteraturan pengobatan, menghindari drop out penderita TBC dengan cara melakukan pengawasan dan pengendalian pengobatan penderita TBC. Salah satu komponen dari Strategi DOTS adalah diagnosis TBC dengan pemeriksaan dahak secara langsung yang cukup spesifik dan sensitif. (Dep. Kes RI, 2003:1).

Menurut data Dinkes Kota Kediri untuk puskesmas Campurejo tentang penemuan dan penanganan pasien baru TB dengan BTA positif terjadi peningkatan penderita TBC yakni tahun 2011 ada 24 penderita, tahun 2012 ada 32 penderita. Hal ini kemungkinan pasien menghentikan program pengobatan sendiri/tidak minta obat lagi (mengalami drop out) dan beberapa orang pengobatannya rutin sampai sekarang.

Hasil studi pendahuluan yang dilakukan pada tanggal 6 September 2012 saat wawancara di puskesmas Campurejo kota Kediri dari 5 orang TBC Paru baru, 3 orang yang terlihat dari perilaku menunjukkan manifestasi kecemasan pasien berupa gelisah, kurang komunikatif dengan pasien lainnya. Kecemasan seringkali digunakan untuk menggambarkan reaksi emosional individu terhadap kejadian yang penuh stress seperti masuk rumah sakit. Kecemasan yang dialami oleh pasien TBC yang dikemukakannya karena batuk dan sesak, kurangnya informasi tentang akibat lanjut dari penyakitnya, banyak dan lamanya obat yang harus diminum serta efek samping dari obat yang dirasakan setelah minum obat TBC tersebut. Efek samping yang sering dikemukakan yang menimbulkan kecemasan tersebut diantaranya rasa mual, anoreksia, dan ingin muntah. Kecemasan akibat TBC Paru bukan saja pada pasien tetapi juga berdampak pada keluarga, hal ini disebabkan karena anggota keluarga resiko tinggi tertular, adanya gejala klinik, isolasi, pengobatan yang lama serta biaya yang cukup mahal ( Marilyn Doenges, 1999 241).
Dengan adanya kecemasan akan mengakibatkan hambatan terhadap penyembuhan pasien. Respon individu terhadap cemas dapat berkurang dengan pelaksanaan asuhan keperawatan secara mandiri. Peran perawat sebagai konselor berfungsi membantu memecahkan masalah secara biopsikospiritual serta memfasilitasi usaha pasien TBC dalam mengurangi/menghilangkan kecemasan.

Menurut penelitian (Sucipto, 2005) pemberian konseling kesehatan dapat menurunkan stress pada pasien Kusta. Konseling kesehatan yang dilaksanakan oleh perawat bermanfaat bagi pasienpasien dengan penyakit Jantung dan penyakit kronis. Pasien yang mengalami kecemasan setelah menerima konseling kesehatan merasakan adanya penurunan kecemasan dibanding pasien yang tidak mendapatkan konseling (Shanley E. Dan Abraham C., 1997). Konseling kesehatan merupakan bagian dari peran perawat secara mandiri yang digunakan dalam bantuan terapeutik ke pasien. Konseling kesehatan merupakan metode implementasi yang membantu klien menggunakan proses pemecahan masalah untuk mengenali dan menangani stres dan memudahkan hubungan interpersonal di antara klien, kelurganya, dan tim perawatan kesehatan ( Perry \& Potter, 2005: 209). Pemberian konseling kesehatan pada pasien TBC paru sangat diperlukan untuk membantu klien agar mampu menguasai masalah yang dihadapi pada waktu yang akan datang sehingga pasien akan menerima keadaan sakitnya (Eisenberg, 1983, yang dikutip Gunarso Singgih, 2001).

Pemberian konseling kesehatan yang efektif diharapkan pasien TBC dapat mengerti dan menerima keadaannya untuk menemukan jalan keluarnya. Selanjutnya pasien TBC dapat mengembangkan potensi dirinya secara nyata dan menyadari keadaannya sehingga kecemasan dapat dikurangi atau dihilangkan (Baraja 2006:12). 
Pelaksanaan Konseling kesehatan yang efektif pada pasien TBC meliputi perubahan pada pemikiran, perasaan dan perbuatan untuk memasuki dunia klien dengan memahami, merasakan, dan membenarnkan diri di dalamnya dengan sadar. Hanya dengan Jalan memasuki dan memahami klien permasalahan klien dapat teratasi (Pujosiswarno, 1992: 38)

Berdasarkan uraian di atas maka peneliti tertarik untuk meneliti tentang pengaruh konseling kesehatan terhadap penurunan tingkat kecemasan pada pasien TBC Paru di wilayah kerja Puskesmas Campurejo Kota Kediri.

\section{Metode Penelitian}

Penelitian ini menggunakan jenis penelitian Pre-eksperimental. Desain yang digunakan adalah One Group Pretestposttest Design. Dimana suatu kelompok sebelum dilakukan perlakuan tertentu $(\mathrm{x})$ diberi pretest kecemasan dengan skala HARS pada pasien TBC baru, kemudian diberikan perlakuan dan sesudah perlakuan tersebut dilakukan post test kecemasan dengan skala HARS. Penelitian ini dilakukan di Puskesmas Campurejo selama Agustus sampai dengan Januari 2013. Teknik sampling yang digunakan adalah purposive sampling dengan kriteria inklusi :
a. Pasien dengan diagnosa TBC Paru baru dengan tanda klinis, BTA Positip dan Foto Rontgen positip
b. Pasien laki-laki atau perempuan yang berumur antara 20 - 60 tahun
c. Pasien TBC Paru baru yang mendapatkan pengobatan
d. Dapat berkomunikasi secara lisan dengan baik.
e. Pasien TBC Paru baru tanpa komplikasi

f. Pasien TBC Paru baru yang bersedia menjadi responder.

Dan kriteria eksklusi pasien TBC Paru dengan BTA negatif. Pelaksanaan konseling kesehatan dilakukan selama 20 menit, frekwensi 1 kali secara individual dengan metode penyuluhan meliputi biopsikososiospiritual. Data yang diperoleh dianalisa dengan Uji Wilcoxon Matched Pairs Test dengan SPSS 10 for Windows dengan taraf kepercayaan $95 \%$ (Santoso,2003).

\section{Hasil Penelitian}

Sebelum dilakukan konseling kesehatan responder diberikan pre test kecemasan dengan skala HARS dengan hasil sbb:

Tabel : 5.1. Distribusi frekuensi Tingkat kecemasan sebelum dilakukan konseling kesehatan pasien TBC Paru

\begin{tabular}{rlll}
\hline No & $\begin{array}{l}\text { Tingkat } \\
\text { Kecemasann }\end{array}$ & Frekuensi & $\begin{array}{l}\text { Prosentase } \\
(\%)\end{array}$ \\
\hline 1. & $\begin{array}{l}\text { Tidak ada } \\
\text { kecemasan } \\
\text { 2. }\end{array}$ & 0 & 0 \\
Cemas ringan & 8 & 32 \\
3. & $\begin{array}{l}\text { Cemas } \\
\text { sedang }\end{array}$ & 8 & 32 \\
5. & Pemas berat & 8 & 32 \\
\hline Total & & 1 & 4 \\
\hline
\end{tabular}

Tabel: 5.2. Distribusi frekuensi Tingkat kecemasan setelah dilakukan konseling kesehatan pasien TBC Paru

\begin{tabular}{llll}
\hline No & $\begin{array}{l}\text { Tingkat } \\
\text { Kecemasan }\end{array}$ & Frekuensi & $\begin{array}{l}\text { Prosentase } \\
(\%)\end{array}$ \\
\hline 1. & $\begin{array}{l}\text { Tidak ada } \\
\text { Kecemasan } \\
\text { Cemas } \\
\text { Ringan }\end{array}$ & 0 & 0 \\
3. & $\begin{array}{l}\text { Cemas } \\
\text { Sedang } \\
\text { Cemas } \\
\text { berat }\end{array}$ & 11 & 36 \\
5. & 5 & 44 \\
\hline Potal & & 0 & 20 \\
\hline
\end{tabular}


Tabel: 5.3 Distribusi frekuensi perubahan Tingkat kecemasan sebelum dan setelah dilakukan konseling kesehatan pasien TBC Paru

\begin{tabular}{clll}
\hline No & $\begin{array}{l}\text { Perubahan } \\
\text { Tingkat } \\
\text { Kecemasan }\end{array}$ & Frekuensi & $\begin{array}{l}\text { Prosentase } \\
(\%)\end{array}$ \\
\hline 1. & Meningkat & 0 & 0 \\
2. & Menurun & 7 & 28 \\
3. & Tetap & 18 & 72 \\
\hline Total & & 25 & 100 \\
\hline
\end{tabular}

Berdasarkan hasil uji Wilcoxon perbedaan penurunan tingkat kecemasan antara kelompok sebelum konseling (pre) dan sesudah konseling (post) pada pasien TBC Paru menunjukkan nilai $\mathrm{Z}$ hitung (-2.449) > Z tabel (-1.96). harga negatif (-) tidak diperhitungkan, karena hanya menunjukkan arah. P-Value $=0.014<0.05 \quad(\mathrm{a}=5 \%)$, sehingga Ho ditolak dan dapat disimpulkan bahwa konseling kesehatan berpengaruh terhadap penurunan tingkat kecemasan pada pasien TBC Paru.

\section{Pembahasan}

\section{Tingkat kecemasan pasian TBC Paru sebelum dilakukan konseling Kesehatan}

Kecemasan pada pasien TBC menurut keadaan responder $72 \%$ kedudukannya sebagai kepala keluarga. Kepala keluarga berperan sebagai sumber pencari nafkah dan berperan dalam memutuskan masalah. Dari Usia $52 \%$ responder berusia $30-39 \%$ hal ini mengalami kecemasan bisa dikarenakan termasuk usia produktif. Semakin tua cenderung mempunyai kecemasn lebih ringan dibandingkan yang muda (Stuart dan Sundden,1998).

Usia produktif merupakan usia untuk mencapai karier bila usia ini sakit mengakibatkan cemas. Jenis kelamin $80 \%$ sebagian besar laki-laki karena hal ini kenyataannya pada waktu penelitian sebagian besar pasien adalah laki-laki. Status perkawinan $72 \%$ responder sudah menikah. Pasien TBC mengalami kecemasan dikarenakan kurangnya kebutuhan seksual bila efek samping terjadi akan mengalami impotensi. Tingkat pendidikan $36 \%$ berasal dari SLTP mengalami cemas, sesuai Stuart dan Sundden bahwa terjadinya kecemasan lebih banyak dialami yang mengalami tingkat pendidikan rendah.Untuk responder dengan jenis pekerjaan $40 \%$ bertani mengalami cemas karena biaya yang mahal dari biaya pengobatan yang lama. Untuk informasi penyakit TBC sebanyak $64 \%$ sudah mendapatkan kecemasan dimungkinkan karena mengetahui efek samping pengobatan dan lamanya berobat. Untuk data perawatan sebagian besar pasien mengalami cemas pada hari ke 2 yaitu 44\% Hal inidisebabkan adanya situasi dan lingkungan yang baru. Kecemasan pada pasien TBC Paru disebabkan oleh kekawatiran pada penyakitnya yang dapat menular ke orang lain serta pengobatan yang lama. Kecemasan akibat TBC Paru bukan saja pada pasien tetapi juga berdampak pada keluarga, hal ini disebabkan karena anggota keluarga beresiko tinggi tertular, adanya gejala klinik, isolasi, pengobatan yang lama serta biaya yang cukup mahal ( Marilyn Doenges, 1999 :241). Adaptasi dengan kondisi lingkungan di rumah dan sikap keluarga yang menyebabkan kecemasan diantara perawat di puskesmas maupun keluarga dan paramedik memakai masker penutup hidung dan mulut sehingga komunikasi terbatas. Keadaan tersebut menyebabkan situasi lingkungan terapeutik kurang. Keadaan pasien yang tidak berdaya yang disebabkan karena penurunan nafsu makan sehingga masalah nutrisi harus diatasi bersama dengan keluarga dan dalam pemenuhan kebutuhan sehari-hari meliputi (biopsikososiospiritual) kurang maksimal dan berpisah dengan anggota keluarga bisa mengakibatkan peningkatan rasa cemas. Kecemasan tersebut terjadi oleh karena ketidak berdayaan pasien, kehilangan kendali, 
perasaan kehilangan fungsi fungsi dan harga diri, kegagalan pertahanan, perasaan isolasi dan kenyataan yang dialami pasien yang tergantung dari kebutuhan seharihari, keinginan, konsep diri, dukungan keluarga, pengetahuan, kepribadian dan kedewasaannya (Hudak dan Gallo, 1997 dan Bostrom, 1995).

\section{Tingkat kecemasan pasian TBC Paru setelah dilakukan konseling kesehatan}

Tingkat kecemasan dari responder yang mengalami kecemasan sesudah dilakukan tindakan konseling kesehatan menunjukkan hasil bahwa kecemasan masih tetap ada, meskipun tingkatannya berkurang yaitu cemas ringan sebanyak 9 orang ( $36 \%), 11$ orang (44\%) megalami cemas sedang, dan 5 orang ( $20 \%$ ) mengalami cemas berat. Menurut skor nilai kecemasan dari 25 orang responder didapatkan 20 orang $(80 \%)$ cemas menurun dan 5 orang $(20 \%)$ cemas tetap. Dari kriteria tingkat kecemasan 7 orang (28\%) menurun dan 18 orang $(72 \%)$ tetap. Hal ini terjadi pada teknik penghitungan skala HARS antara skor 1 dan 2 kurang jelas sehingga mempengaruhi penggolongan kriteria kecemasan. Menurut Nismith dkk, pasien-pasien dengan penyakit Jantung yang mengalami kecemasan setelah menerima konseling secara berulang dang 2 kali seminggu merasakan hasil yang lebih baik pada 6 bulan dari pada yang tidak mendapat konseling (Abraham \& Shanley, 1997).

Pada penelitian (Sucipto, 2005) membuktikan bahwa konseling kesehatan yang dilakukan selama 15 menit berpengaruh terhadap penurunan stres pada pasien Kusta. Kemungkinan kecemasan tetap ada Konseling kesehatan yang dilakukan pada pasien TBC paru dengan berdasar komunikasi dan hubungan terapeutik. Komunikasi terapeutik ke pasien berdampak akan terjalin perasaan saling menghargai dan saling mempercayai. Pelaksanaan konseling kesehatan yang dilakukan peneliti dalam waktu 20 menit dengan frekwensi 1 kali. Untuk menciptakan kondisi saling mempercayai antara konselor dengan pasien tentunya membutuhkan waktu dan sering berinteraksi, sehingga hal ini yang mungkin mengakibatkan kecemasan masih tetap ada.

Menurut Latipun (2001)

keberhasilan konseling pada pelaksanaannya dipengaruhi oleh banyak faktor, salah satunya adalah yang berhubungan dengan karakteristik subyek. Karakteristik tersebut adalah kondisi subyek, tingkat pendidikan, kondisi rumah tangga dan pengalaman. Kondisi responder yang terdiri dari fungsinya di keluarga dan status pernikahan juga mengakibatkan cemas. Tingkat pendidikan pasien juga bermacam-macam yang mempengaruhi dalam pelaksanaan konseling.

Dari segi ekonomi menganjurkan ke pasien untuk mempergunakan ASKES GAKIN dan Jamkesmas untuk meringankan biayanya, mengingat sebagian besar penderita TBC dari keluarga miskin. Sikap dan cara memandang pasien terhadap diri dan lingkungannya akan berbeda dalam menyikapi proses berlangsungnya konseling pada dirinya. Konseling kesehatan merupakan intervensi keperawatan dengan cara mengaktifkan/memecahkan masalah pasien dengan dukungan emosional, intelektual, spiritual dan psikologis sehingga memberikan pengurangan respon psikologis (Perry \& Potter, 2005).

Konselor memberikan informasi tentang penyakit TBC dengan disertai dukungan psikologis, sosial dan spiritual. Pemenuhan kebutuhan sosial dengan mengajak bercakap cakap dengan pasien dan keluarga dengan penuh empati. Pemenuhan spiritual pasien yang dirawat terutama ibadahnya tidak dijalankan karena kondisinya. Konselor memenuhi kebutuhan spiritual dengan memberi 
solusi agar pasien menjalankan ibadahnya sesuai dengan kondisi. Sikap, posisi, pasien dalam menerima konseling bervariasi sehingga pelaksanaan konseling kurang maksimal. Selain itu pasien merasa kecapekan dalam posisi duduk. Peneliti menggunakan masker penutup hidung dan mulut meskipun kadang-kadang masker dibuka jika pasien tidak jelas dalam menerima konseling. Keberhasilan konseling dalam memecahkan masalah akan berhasil jika ada sikap bertatap muka dengan posisi duduk, dalam suasana tenang, privasi, empati dan ketulusan serta penempilan yang menarik, saling terbuka (Singgih,2001). Peneliti menganalisa, kecemasan yang tetap disebabkan pasien barn mengenal konselor, waktu perkenalan dan pemberian konseling hanya 1 kali dengan waktu 20 menit dan kondisi dari pasien karena berpisah dengan orang yang dicintai yaitu meninggal dunia atau perceraian.

\section{Perbedaan tingkat kecemasan pasien TBC Paru sebelum dan sesudah dilakukan konseling kesehatan}

Dari hasil uji pretest dan posttest pemberian konseling kesehatan didapatkan 2 nilai mean yang berbeda atau mengalami penurunan antara pretest dan posttest konseling. Dari uji Wilcoxon menunjukkan nilai $\mathrm{Z}$ hitung $=-2.449$ dan $\mathrm{Z}$ tabel $=-1.96 \quad($ tanda negatif tidak diperhitungkan karena hanya menunjukkan arch) dengan P-value sebesar 0.014. Dimana P-value lebih kecil dari alpha $0.05(\mathrm{a}=5 \%)$ artinya konseling kesehatan berpengaruh terhadap penurunan tingkat kecemasan pada pasien TBC Paru.

Aktivitas konseling lebih berhasil jika terjadi komunikasi dan hubungan terapeutik yang berdasar pada kepercayaan dan respek (rasa hormat) pasien serta mempunyai rasa empati, kehangatan, privasi dan memastikan kenyamanan pasien serta seringnya pertemuan (Gloria dan Joanne,1997).
Konseling kesehatan merupakan usaha yang dilakukan perawat untuk membantu pasien secara holistik dalam menghadapi perubahan yang actual dengan cara member dukungan emosional, intelektual, spiritual dan psikologis (Perry \& Potter, 2005). Konseling kesehatan merupakan tindakan dari peran perawat yang bertujuan untuk membantu permasalahan pasien baik. Pemberian konseling dilakukan untuk menanamkan koping adaftif (menerima realita). Permasalahan pasien perlu dipecahkan dengan mengembangkan mekanisme koping. Pengembangan koping dalam menangani kecemasan dipengaruhi oleh banyaknya faktor yang ikut mempengaruhi tingkat kecemasan pada setiap individu antara lain kondisi individu, karakteristik kepribadian, sosial kognitif, dukungan sosial, serta strategi koping yang dilakukan (Kaplan dan Saddock, 1999).

Intensitas tingkat kecemasan dapat meningkat, menurun atau tetap tergantung pada kemampuan koping individu dan sumber-sumber pada waktu tertentu. (Brunner dan Suddarth, 2005). Pelaksanaan konseling sebaiknya sudah terjalin hubungan yang terapeutik antara konselor dengan konsel dan konselor juga megetahui dari kondisi lingkungan hidup dari pasien yang meliputi jenis kelamin, keadaan keluarga, kebudayaan, status sosial, waktu, tempat dan keturunan. Struktur interaksi terapeutik dengan memperlihatkan sikap bersahabat, bertutur kata yang lembut, jelas tegas, penuh perhatian, peka terhadap kebutuhan pasien, mampu memotivasii pasien untu berinteraksi dengan berbagi pengalaman. Konseling ini akan memperoleh hasil yang baik apabila dilakukan secara teratur dan berkesinambungan. Hal ini perlu diteliti lebih lanjut tentang frekwensi, waktu, tempat pelaksanaan konseling kesehatan serta faktor-faktor yang mempengaruhi kecemasan pasien. Dari data dan teori di atas maka bisa disimpulkan bahwa pelaksanaan konseling pada pasien TBC tidak sepenuhnya 
menurunkan kecemasan Pasien TBC. Hal ini disebabkan karena waktu pada penelitian ini terbatas sehingga dalam pemberian konseling kurang optimal. Pemberian konseling kesehatan yang meliputi biopsikospiritual secara berkala dan berkesinambungan pada pasien TBC perlu dilakukan dalam menurunkan kecemasannya.

\section{Kesimpulan}

1. Dari hasil pengukuran tingkat kecemasan pasien TBC Paru sebelum dilakukan Konseling kesehatan didapatkan hasil $32 \%$ kategori cemas ringan, sedang, berat dan $4 \%$ orang kategori panik.

2. Tingkat kecemasan pasien TBC Paru sesudah dilakukan konseling kesehatan menunjukkan pengurangan tingkat kecemasan dengan hasil cemas ringan sebanyak $36 \%, 44 \%$ megalami cemas sedang, dan $20 \%$ mengalami cemas berat

3. Uji statistik Wilcoxon Matched Pairs Test dengan hasil $\mathrm{Z}$ hitung $=2.449 \mathrm{dan}$ P-Value $=0.014<(a=5 \%)$, sehingga Ho ditolak artinya konseling kesehatan berpengaruh terhadap penurunan tingkat kecemasan pada pasien TBC Paru yang sedang menjalankan pengobatan.

\section{SARAN}

1. Untuk Praktek Keperawatan Sebagai perawat yang profesional harus mampu melihat kebutuhan klien, tidak hanya kebutuhan biologis (fisik) tetapi juga kebutuhan psiokolgis, sosial dan spritual, untuk itu perlu dikembangkan tindakan keperawatan pada pasien TBC Paru dengan mengunakan

2. Konseling kesehatan dalam memecahkan masalahnya.Untuk Puskesmas sebaiknya dalam menyusun perencanaan revitalisasi kinerja untuk mencapai kualitas pelayanan yang komprehensip dibentuk tim konselor dalam pelaksanaan konseling kesehatan dan perlunya dibuat prosedur tetap bagi pasien TBC paru baik yang menjalani rawat jalan saat mengambil obat

\section{Daftar Pustaka}

Abraham C \& Shanley E, 1997, Psikologi Sosial Untuk Perawat, EGC,Jakarta

Baraja A, 2006, Psikologi Konseling dan Teknik Konseling, Studio Press, Jakarta

Brain Explorer, Hamilton Anxiety Rating Scale (HAM_A) (online)

(http://www

brain Explorer.org/depression. shtm.diakses 10 September 2012

Brunner \& Suddarth, 2005, Buku Ajar Keperawatan Medikal Bedah, EGC, Jakarta

Depkes RI, 2003, Prosedur Tetap Pencegahan dan Pengobatan Tuberculosis pada Orang dengan HIV/AIDS, Depkes RI, Jakarta

Gunarso Singgih, 2001, Konseling \& Psikoterapi, Gunung Mulia, Jakarta

Gloria dan Joanne, 1997, Nursing Intervension Clasification,Philadelphia

Kaplan dan Saddock, 1999,Sinopsis dan Praktek Ilmu Kesehatan, EGC, Jakarta

Latipun, 2001, Psikologi konseling, ed 3, Unmuh Malang

Marilyn Doenges, 1999,Dokumentasi

Keperawatan, EGC Jakarta.

Pooter \& Perry, 2005, Buku Ajar

Fundamental Keperawatan, Vol.1, EGC Jakarta

Pujosiswarno, 1992, Petunjuk Praktis

Pelaksanaan Konseling,Ed 1, Menara Mas Yogyakarta

Shanley E. Dan Abraham C., 1997, Psikologi Sosial Untuk Perawat, EGC, Jakarta

Stuart dan Sudden, 1998, Buku Saku Keperawatan Jiwa, ed 3, EGC, Jakarta 
Sucipto, 2005,Skripsi, Pengaruh

konseling Kesehatan terhadap

Penurunan stress pada pasien

Kusta yang ditandai penurunan

kadar kortisol darah, STIKES Surya

Mitra Husada Kediri.

Soedarto, 2009, Penyakit Menular di

Indonesia, Cetakan I, CV Sagung

Seto,Jakarta 